\title{
ANALYSIS OF THE CONNECTIONS BETWEEN LIFELONG LEARNING AND SOCIAL COMPETENCES OF HUMAN RESOURCES \\ Dávid Miško ${ }^{1}$, Matúš Vagaš ${ }^{2}, Z_{\text {Zuana Birknerová }}{ }^{,}$Juraj Tej $^{4}$, Eva Benková $^{5}$
}

\begin{abstract}
The primary aim of the research was to find out the existence of statistically significant connections between the assessment of the effectiveness of lifelong learning and the identification of social competence by human resources who completed social competence development training and those who did not. The starting point for data collection was the VVOS questionnaire concerning the effectiveness of lifelong learning, and the AKMK questionnaire focused on identifying social competence. The research was conducted on a sample of 211 human resources, of which 118 (55.9\%) were women and 93 (44.1\%) men aged from 23 to 66 years. Using correlation analysis, we identified statistically significant connections between the factors for assessing the effectiveness of lifelong learning and the factors for identifying the social competence of human resources, who have completed training to develop social competence.
\end{abstract}

UDC Classification: 005.95/0.96, DOI: https://doi.org/10.12955/pss.v2.232

Keywords: lifelong learning, social competence, human resources development

\section{Introduction}

This paper aims to verify the statistically significant relationship between the evaluation of the effectiveness of lifelong learning and the identification of social competence by human resources between groups of respondents who have received training on the development of social competence and those who have not. The goal of lifelong learning is to achieve the necessary qualifications at any time during life (Palán, Langer, 2008). Morovič (2011) defines lifelong learning as a combination of formal education (school system) and non-formal learning (knowledge also from other sources). According to Dvořáková, Šerák (2016), lifelong learning is carried out in all phases of human life, and countless situations and diverse environments in which people find themselves contribute to such education. Lifelong learning focuses on meeting the diverse and context-specific educational needs of all age groups. Learning and adult education, vocational training and literacy are an important part of the lifelong learning process (United Nations Educational, Scientific and Cultural Organization, 2015). Lifelong learning is a theoretical and practical concept that states that it is possible and necessary for human beings to constantly acquire information, knowledge, and competences throughout life for personal or professional reasons. (Sartori et al., 2018). ISHN (Industrial Safety \& Hygiene News, 2014) states that lifelong learning is the minimum requirement for success in a given field of work. It is a tool for increasing performance, maintaining motivation, improving existing skills, morals, and employee satisfaction (Little, 2011). Research in the field of lifelong learning has the potential to contribute to a sustainable working life in terms of providing more flexible measures for employees and supporting lifelong learning, which takes place in different contexts (office, online, etc.). It is important to increase knowledge about lifelong learning practices in this area (Bjursell et al., 2021).

\section{Literature review}

So far, education has been the most common form of face-to-face meetings. The COVID-19 pandemic has made online education a common form. In order to continue education in the pandemic world, it is necessary to change the procedures and content of education constantly. It is also necessary to focus on the future of education with regard to lifelong learning (Nørgård, 2021). According to Kachaňáková et al. (2011), training and development in the organization can be described as a necessity. Each organization's nature, intensity, and level are different as it adapts to corporate needs. This process must be systematic, well-organized, and occur in a recurring cycle (identifying real learning needs, planning, tailor-made training and development activities, monitoring, and determining the success rate of training and human resources development. Mikuláśtík (2015) adds that the planned process has a positive impact on mental resilience, self-control, effective work performance, and the development of human resources potential. Human resources will gain the necessary knowledge, which they will use better to understand the work environment (Folwarczná, 2010). ISHN (Industrial Safety \& Hygiene News, 2014)

\footnotetext{
${ }^{1}$ University of Prešov, Faculty of Management, Prešov, Slovakia, david.misko@ smail.unipo.sk

${ }^{2}$ University of Prešov, Faculty of Management, Prešov, Slovakia, matus.vagas@ @mail.unipo.sk

${ }^{3}$ University of Prešov, Faculty of Management, Prešov, Slovakia, zuzana.birknerova@unipo.sk

${ }^{4}$ University of Prešov, Faculty of Management, Prešov, Slovakia, juraj.tej@unipo.sk

${ }^{5}$ University of Prešov, Faculty of Management, Prešov, Slovakia, eva.benkova@unipo.sk
} 
describes the need for continuous education, development, and training of human resources to help them achieve the results they are responsible for. Human resource training is a specific part of the learning process. At this stage, they acquire skills important for a better performance of their work (Folwarczná, 2010). The most relevant and realistic training activities possible help them to acquire specific knowledge at a professional level. The goal of the training should be clearly defined in terms of the required behavior that should be the result of the training (Armstrong, Taylor, 2014). On the one hand, many countries face a "teaching crisis", although they have made remarkable progress in improving access to education at all levels. On the other hand, a discrepancy in skills is growing to the point where many graduates cannot find employment. At the same time, employers are often unable to fill vacancies due to the changing nature of skills and jobs (Panth, Maclean, 2020).

\section{Social competences of human resources}

It turns out that managers are not ready to manage corporate resources in a high-risk environment. Considering the problems of managers requires the achievement of theoretical and practical knowledge of competences formed in unpredictable conditions (Drozdowski et al., 2021). Competence is an ability (behavior, activity, or complex of activities) characterized by excellent performance in some field of activity. The social competences of human resources include the abilities, motivation, knowledge, skills to do well what is required in the field. Key competences are suitable for solving a number of mostly unforeseen problems that will enable human resources to successfully cope with rapid changes at work (Seemann, 2016). Korenková (2014) complements them with building relationships, inspiring, communicating with a good response, motivating and developing others, cooperating and creating an environment for teamwork. Seková et al. (2013) also mention the ability to treat people inside and outside the organization and the social ability to assert oneself in social relationships. The research focused on selected social competences of human resources, namely assertiveness, stress management, communicativeness, people management and systematic planning. Assertiveness is a property by which individuals are not subjected to manipulation by others (Lojda, 2011). Assertiveness is one of the most important qualities that people can learn. It can be considered as the so-called key to quality and positive relationships (Garner, 2012). Assertive communication refers to a person's ability to initiate, maintain, and end a conversation based on their individual goals.

Being assertive means that communication is dominant, vigorous, directive, competitive and taskoriented, which is often associated with masculine characteristics (Men 2021). Stress is a condition in which individuals feel a psychological burden or find themselves in a stressful situation and are affected by a certain disturbing factor (Seemann, 2016). In recent decades, work-related stress has been a major, complex and costly phenomenon worldwide. Globalization and the global financial crisis seriously affect the workplace environment, leading to increased stress and related problems (Fortes, Tian, Huebner, 2020). Coping with challenging tasks is difficult to do without human resources feeling stressed (Mikuláštík, 2015). There are differences between individuals in how they cope with increased work demands and stressful situations. Stress is the interaction between an individual and his environment. The difference between the perceived requirements of the situation and the perceived ability of the individual to cope with the situation (McFadden et al., 2021). It is necessary to learn how to manage stress and stressful situations and eliminate their effects on your health and work performance (Seemann, 2016). Communication is part of all activities that take place in companies. It is needed to coordinate business activities. Its task is to transmit as much information as possible with the least possible losses. Therefore, it is necessary to pay attention to efficiency and reliability in communication (Korenková, 2014). The desire to form expected competences is evidence of the growing awareness that competent people are the primary source of corporate value creation (Kohnová et al., 2020). Therefore, there is an increasing emphasis on exploring different competences.

\section{Data and methodology}

The research aimed to find out the existence of statistically significant connections between the assessment of the effectiveness of lifelong learning and the identification of social competences in human resources who participated in social competence development training and in those who did not. The research was conducted on a sample of 211 human resources, out of which 118 (55.9\%) were women and $93(44.1 \%)$ men aged from 23 to 66 years (average age 38.72 years, standard deviation 10.026). In terms of inclusion in the organization, the research sample consisted of 50 (23.7\%) executive employees, 61 (28.9\%) first-level managers, 56 (26.5\%) middle managers and 44 (20.9\%) top managers. 
Training in the development of social competences of human resources was attended and completed by $310(61.6 \%)$ respondents, and $81(38.4 \%)$ respondents did not attend any training in the development of social competences of human resources.

The research was conducted using the VVOS questionnaire (Frankovský et al., 2015) and the AKMK questionnaire (Tittesi, 2010). The VVOS (Significance, Benefits, Expectations, Satisfaction) human resources questionnaire answered questions concerning the effectiveness of lifelong learning.

The effectiveness of corporate training was identified with an original methodology VVOS (in the Slovak language - in English Significance, Benefits, Expectations and Satisfaction (SBES). This questionnaire consisted of 22 items. Based on them, the respondents evaluated various aspects of corporate training. Each item was assessed on a 5-point scale, where 1 meant - certainly no, 2 - rather no, 3 - neither no, nor yes, 4 - rather yes, 5 - certainly yes.

Four factors were extracted using the Principal Component Analysis with Varimax Rotation. The content of these 4 factors can be described as follows: F1: Significance for the profession - respondents scoring high in this factor assign greater significance to education for the profession; they perceive a greater personal significance of training and perceive a higher degree of relation to the work performance. F2: Benefits for the employees - respondents with higher scores in this factor attribute greater importance to training for career development, positive evaluation, improvement of relationships in the workplace, and motivation increase. F3: Expectations of the employees - the respondents scoring high in this factor express positive evaluation of the training program, educational methods and forms used, and the training course and their expectations are higher. F4: Satisfaction of the employees respondents with higher scores in this factor evaluate training as more comprehensible, acceptable, and adequate time-wise (Frankovský et al., 2015).

The starting point for data collection was the AKMK questionnaire - Current key management competences used in the Tittesi project (2010). Based on the mentioned methodology, it is possible to identify 20 social competences based on self-assessment of 60 statements (initiative; innovation management; problem-solving and risk-taking; organizational flexibility; self-confidence; assertiveness; knowing and acting according to opportunities; stress resilience; networking and cooperation; systematic planning; knowledge of law and economics; performance orientation; awareness of high-quality work; orientation to people; interpersonal skills: communication and acceptance of differences; personality skills: perseverance and ability to persuade; project development and implementation; information retrieval; ability to maintain customer relationships and sensitivity to customers; use of impact strategies).

Individual items were assessed by human resources on a 5-point scale from 0 to 4 (certainly no; no; neither yes nor no; yes; certainly yes). The mentioned social competences can be combined in terms of content into 4 factors:

1. Assertiveness (assertiveness; ability to maintain customer relationships and sensitivity to customers; self-confidence; use of impact strategies; innovation management)

2. Stress management (resistance to stress; ability to solve problems and take risks; awareness of the high quality of work; know and act according to opportunities; organizational flexibility)

3. Communicativeness (interpersonal skills: communication and acceptance of differences; personality skills: perseverance and ability to persuade; networking and cooperation; information retrieval; orientation to people)

4. People management (systematic planning; knowledge of law and economics; project development and implementation; use of impact strategies; performance orientation)

Based on the research goal, we set the hypothesis: "We assume that there are statistically significant connections between the assessment of the effectiveness of lifelong learning and the identification of social competences of human resources who completed and those who did not attend social competence development training".

\section{Results}

Pallant (2020) and Field (2013) with a research sample size above 200 recommended data for normally distributed. In the case of a large sample, a breach of the obligation to test the normality of data distribution is acceptable. Knief, Forstmeier (2021) found that Gaussian models are resistant to abnormality, meaning that $\mathrm{p}$-values remain relatively reliable, with routine data with outliers influenced 
at stringent alpha levels. The hypothesis was verified using correlation analysis (Pearson's correlation coefficient). Statistically significant connections between the assessment of the effectiveness of lifelong learning and the identification of the social competences of human resources who have completed development training are presented in Table 1.

Table 1: Connections between assessing the effectiveness of lifelong learning and identifying the social competences of human resources who completed training

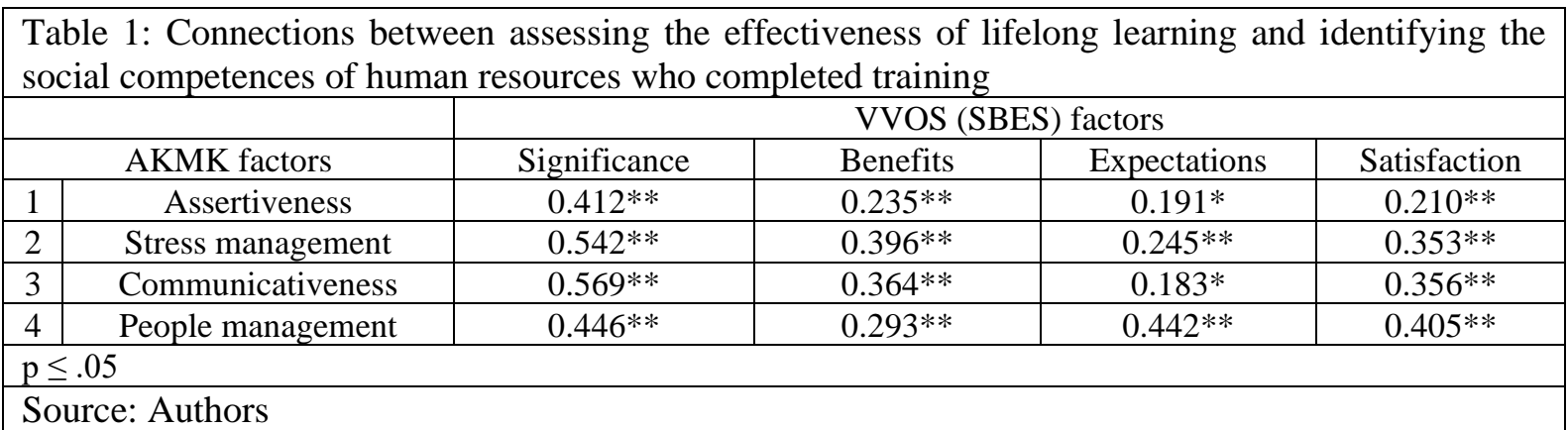

Using the correlation analysis (Table 1), statistically significant connections were confirmed between all factors of assessing the effectiveness of lifelong learning and all factors of identifying the social competences of human resources. Those individuals who perceive the personal importance and importance of education for their profession and the performance of their work correlated most in the social competence Communicativeness (.569), Stress management (.542), People management (.446) and assertiveness (.414). Respondents who have already completed training aimed at developing the potential of human resources see lifelong learning as important for career growth, for their positive evaluation, for improving relationships in the workplace, and for increasing motivation. These respondents also positively assessed higher expectations and satisfaction with its implementation and focused on developing the examined social competences.

The existence of statistically significant connections by the respondents who did not attend training in human resources development was also examined. The obtained correlation analyses are presented in Table 2.

Table 2: Connections between assessing the effectiveness of lifelong learning and identifying the social competences of human resources who did not attend training

\begin{tabular}{|c|c|c|c|c|c|}
\hline & & \multicolumn{4}{|c|}{ VVOS (SBES) factors } \\
\hline \multicolumn{2}{|r|}{ AKMK factors } & Significance & Benefits & Expectations & Satisfaction \\
\hline 1 & Assertiveness & $0.438 * *$ & 0.149 & $0.141 *$ & 0.197 \\
\hline 2 & Stress management & $0.417 * *$ & 0.016 & 0.129 & 0.123 \\
\hline 3 & Communicativeness & $0.309 * *$ & 0.120 & $0.196 *$ & 0.129 \\
\hline 4 & People management & $0.306 * *$ & 0.203 & $0.142 *$ & 0.165 \\
\hline \multicolumn{6}{|c|}{$\mathrm{p} \leq .05$} \\
\hline \multicolumn{6}{|c|}{ Source: Authors } \\
\hline
\end{tabular}

Table 2 presents the connections between the assessment of lifelong learning (VVOS) effectiveness and the identification of social competences (AKMK) of human resources who have not attended the training. We present higher statistically significant correlations between the importance of lifelong learning and all factors of the AKMK methodology - Assertiveness (.438), Stress management (.417), Communicativeness (.309), People management (.306). Expectations from lifelong learning are statistically lower correlated with the competences-Communication, People management and Assertiveness. Benefits and Satisfaction with lifelong learning of human resources do not statistically correlate with any social competence. Here we see a difference in those respondents who have not yet completed potential development training.

Based on the above analyses, it can be stated that the hypothesis: "We assume that there are statistically significant connections between the assessment of the effectiveness of lifelong learning and the identification of social competences of human resources who completed and those who did not attend any social competence development training" was confirmed. 


\section{Discussion and conclusion}

The aim of our research was to find out the existence of statistically significant connections between the assessment of the effectiveness of lifelong learning and the identification of social competencies by human resources who completed training in the development of social competences and those who did not. The starting point for data collection was the VVOS questionnaire on the effectiveness of lifelong learning and the AKMK questionnaire aimed at identifying social competences.

The research was focused on the social competences of human resources in the context of lifelong learning. The VVOS methodology was designed and applied by Frankovský et al. (2015). Their findings suggest that the assessment of lifelong learning does not form a homogeneous whole but that it is possible to specify certain structural elements of this assessment. The authors consider the extracted and content-specified factors of VVOS to be one of the possible approaches to the assessment of lifelong learning. The suitability of the VVOS methodology was also confirmed by the results of the analysis of differences in the assessment of this training between managers and non-managers.

The issue of the need for lifelong or corporate training is addressed by several authors (e. g. Armstrong, Stephens, 2005; Lancer et al., 2016; Rice, Gregor, 2016). The benefits of effective corporate training correspond with those reported by Armstrong (2007). Effective training and human resource development enable an organization to face change and enables the evolving workforce to design and implement that change (Fitzgerald, 1992). Buckley, Caple (2004) specified two types of training needs in the work process, namely reactive, performance needs, and proactive needs, taking initiatives that are related to the organization's strategies and long-term goals, as well as the human resources plan.

The issue of human resources development and key managerial competences was also dealt with by the authors Frankovský, Birknerová (2018), who carried out data collection using the AKMK questionnaire. Using factor analysis, they extracted two second-order factors, which they specified as "strategy" and "tactics". Based on them, they subsequently designed the LISN model, in which they described four basic types of managers: Leader, Implementer, Strategist and Non-manager. They described the LISN model as a generalized view of managerial competences, including the definition of 4 basic managerial positions. By connecting the LISN model with identifying selected managerial competences, a "guide" is created on how to effectively predict managerial behaviour (Frankovský, Birknerová, 2018).

The need for effective lifelong learning of human resources lies in the more effective use of human potential, i.e., important elements of the organization's competitiveness. The issue of effective assessment of lifelong learning is also important in terms of future motivation to learn. The results of our research show that individuals who have completed training in potential development and were satisfied with the forms of education will continue to learn, develop their potential and social competences in the future. Individuals who did not attend such a training or are dissatisfied with education do not see the importance and benefits of developing social competences and will avoid learning in the future. In further research, it is possible to extend the researched issue by identifying the differences between the examined phenomena in terms of socio-demographic indicators of human resources.

\section{Acknowledgement}

The paper is funded by the Grant agency PU GaPU 32/2020.

\section{References}

Armstrong, M. (2007). Ř́zení lidských zdrojů: Nejnovější trendy a postupy [Human Resources Management: Latest Trends and Procedures]. Praha: Grada Publishing, a. s., 789 p.

Armstrong, M., Stephens, T. (2005). A handbook of management and leadership. London and Sterling, VA: Kogan Page. Armstrong, M., Taylor, S. (2014). Armstrong'S Handbook of Human Resource Management Practice. London: Kogan Page Limited.

Bjursell, C., Bergmo-Prvulovic, I., \& Hedegaard, J. (2021). Telework and lifelong learning. Frontiers in Sociology, 6, 642277.

Buckley, R., Caple, J. (2004). Trénink a školení [Training and Schooling]. Brno: Computer Press, 288 p.

Dvořáková, M., Šerák, M. (2016). Andragogika a vzdělávaní dospělých. Vybrané kapitoly. [Andragogy and Adult Education. Selected Chapters] Praha: Univerzita Karlova, Filozofická fakulta.

FIELD, A., 2013. Discovering Statistics Using IBM SPSS STATISTICS. The University of Sussex. ISBN 978-1-4462-49178. 
Fitzgerald, W. (1992). Training Versus Development. In: Training \& Development, 46, 5, P.81-83.

Folwarczná, I. (2010). Rozvoj a vzdělávání manažerů [Development and Training of Managers]. Praha: Grada Publishing, a. S.

Frankovský, M., Birknerová, Z. (2018). Možnosti identifikácie a špecifikácie klúčových manažérskych kompetencií [Possibilities of identification and specification of key managerial competences]. In Sociální procesy a osobnost 2017, Brno. Praha: Akademie věd České republiky, p. 68-73.

Frankovský, M., Birknerová, Z., Štefko, R., Zbihlejová, L., Zahatňanská, M. (2015). Possibilities of Determining the Effectiveness of Corporate Training. In World Congress on Education. WCE 2015: World congress on education, Dublin: Infonomic society, p. 58-62.

Garner, E. (2012). Assertiveness: Re-claim your assertive birthright. Ventus Publishing ApS (e-book)

ISHN. (2014.) The importance of lifelong learning \& continuous education. [online] [access date 11/19/2020]. Available from:https://www.ishn.com/articles/97998-the-importance-of-lifelong-learning-continuous-education

Kachaňáková, A., Nachtmannová, O., Joniaková, Z. (2011). Personálny manažment [Personnel Management]. Bratislava: Iura Edition, spol. s. r. o.

Knief, U., \& Forstmeier, W. (2021). Violating the normality assumption may be the lesser of two evils. Behavior Research Methods. doi:10.3758/s13428-021-01587-5.

Kohnová, L., Papula, J., Papulová, Z., Stachová, K., \& Stacho, Z. (2020). Job mismatch: the phenomenon of over skilled employees as a result of poor managerial competence. Journal of Entrepreneurship and Sustainability Issues, 8(1), 83-102. Korenková, M. (2014). Základy manažmentu [Basics of Management]. Nitra: Univerzita Konštantína Filozofa v Nitre. Lancer, N., Clutterbuck, D., Megginson, D. 2016. Techniques for coaching and mentoring. New York: Routledge.

Little, J. (2011). Corporate Learning: Training \& Performance. [online] Houston: Houston Community Collage [access date 11/19/2020]. Available from: http://tlr.hccs.edu/facultyportal/pdf/ TL3010Handbook.pdf

Livečka, E. A Kol. (1981). Výchova a vzdělávaní dospělých v zahraničí I [Adult Education Abroad I]. Praha: Státní pedagogické nakladatelství

Lojda, J. (2011). Manažerské dovednosti [Managerial skills]. Praha: Grada Publishing, a. s.

Lukáč, E. (2010). Výchova a vzdelávanie dospelých z pohl’adu vybraných internacionalizačných úsilí v 20. storočí [Adult education from the point of view of selected internationalization efforts in the 20th century]. Prešov: Filozofická fakulta Prešovskej univerzity.

McFadden, P., Ross, J., Moriarty, J., Mallett, J., Schroder, H., Ravalier, J., ... Gillen, P. (2021). The role of coping in the wellbeing and work-related quality of life of UK health and social care workers during COVID-19. International Journal of Environmental Research and Public Health, 18(2), 815.

Men, L. R. (2021). The impact of startup CEO communication on employee relational and behavioral outcomes: Responsiveness, assertiveness, and authenticity. Public Relations Review, 47(4), 102078.

Mikuláštík, M. (2015). Manažerská psychologie [Managerial Psychology]. Praha: Grada Publishing, a. s.

Moreno Fortes, A., Tian, L., \& Huebner, E. S. (2020). Occupational stress and employees complete mental health: A crosscultural empirical study: International Journal of Environmental Research and Public Health, 17(10), 3629.

Morovič, J. (2011). Manažment znalostí a otvorené vzdelávanie. Celoživotné učenie sa. Učiaca sa organizácia [Knowledge Management and Open Education. Lifelong learning. Learning Organization]. Ružomberok: Katolícka univerzita v Ružomberku.

Nagyová, L., Višňovský, J., Šajbidorová, M., Kapsdorferová, Z. (2011). Manažérske zručnosti a riadenie kvality [Managerial skills and Quality Management]. Metodická př́ručka [Methodology Guide]. Nitra: SPU v Nitre.

Nørgård, R. T. (2021). Theorizing hybrid lifelong learning. British Journal of Educational Technology: Journal of the Council for Educational Technology, 52(4), 1709-1723.

Palán, Z., Langer, T. (2008). Základy andragogiky [Fundamentals of Andragogy]. Praha: Univerzita Jana Amose Komenského.

Pallant, J., 2020. SPSS Survival Manual. ISBN 9781003117452.

Panth, B., \& Maclean, R. (2020). Introductory overview: Anticipating and preparing for emerging skills and jobs-issues, concerns, and prospects. In Education in the Asia-Pacific Region: Issues, Concerns and Prospects (pp. 1-10). Singapore: Springer Singapore.

Rice, S.E, Gregor, M.N. (2016). E-learning and the Academic Library: essays on innovative initiatives. North Carolina: McFarland \& Company, Inc.

Sartori, R., Costantini, A., Ceschi, A., \& Tommasi, F. (2018). How do you manage change in organizations? Training, development, innovation, and their relationships. Frontiers in Psychology, 9, 313.

Seemann, P. (2016). Psychológia v práci manažéra [Psychology in Manager's Work]. Žilina: EDIS.

Seková, M. A Kol. (2013). Manažment II. Ludia v organizácii a organizačná kultúra. [Management II. People in Organization and Organizational Culture]. Bratislava: Iura Edition, spol. s. r. o.

Tittesi. (2010). Projekt „Transfer inovatívnych tréningových nástrojov pre skvalitnenie podnikatel’ských zručností“ ["Transfer of innovative training tools to improve entrepreneurial skills". Bratislava: Slovenská obchodná a priemyselná komora. 